\title{
The Neglected Case of the 'W': Waste or Wisdom?
}

\author{
Sridhar Ramachandran $^{1}$ and Annette Wyandotte ${ }^{2}$
}

\begin{abstract}
Institutional withdrawal policies allow students with academic and personal difficulties to avert or minimize damage to the GPA by dropping a course in which they may risk a grade of ' $D$ ' or ' $F$,' or to reduce credit hours to better manage those that remain. Offsetting costs involve lost tuition, delay of progress, and perhaps wasted effort. Yet in the pressures of the moment, how likely are students to weigh competing factors before acting? Do they consider the implications for financial aid, satisfactory academic progress, admission to the major, or timely progress toward a degree? What duties may the institution share with students to promote informed judgments? The authors explore the rewards and risks of dropping a course in view of the literature on the ' $W$.' Further, they explicate their own case study of withdrawal behaviors in an introductory course to the Informatics major to address questions raised in light of the growing literature on student retention and persistence. "What ties may exist between dropping a course and dropping out of college?" "How may student success studies guide institutions and faculty to assist students facing ' $W$ ' decisions?" "Of what benefit may this kind of intervention be for them?" For example, "How may proactive assistance in the ' $W$ ' process encourage students to pursue the competencies of a college degree amid discomfort and frustration likely having both cognitive and affective elements?" "How may students who persist through this challenge be better prepared for the complexities of their lives and work?" (Kuh, Kinzie, Schuh, \& Whitt, 2010).
\end{abstract}

Keywords: withdrawal, 'DFW' attrition, college students, student success, retention, persistence to graduation, drop-out prevention, drop-out research

\section{Introduction}

The authors first learned of studies on student success as part of a chancellor-appointed task force to inform the campus in its effective principles and practices for strategic planning. In the last weeks of this multi-year project, each participant was invited to conduct a short-term inquiry to benefit a specific academic unit. ${ }^{3}$ Unaware then of studies on the ' $\mathrm{W}$,' the authors took a student-success perspective in the small case study presented below, to examine withdrawal across a core introductory course in a major within the School of Natural Sciences. Though realizing that the design would not permit generalization, they expected it to provide helpful

\footnotetext{
${ }^{1}$ Associate Professor, Informatics Department, Indiana University Southeast, Indiana, USA, sriramac@ius.edu ${ }^{2}$ Assistant Vice Chancellor for Academic Affairs and Professor of English, Indiana University Southeast, Indiana, USA, awyandot@ius.edu

${ }^{3}$ The work of the task force occurred at the authors' four-year, public comprehensive university in 2013-2015; for demographics, see n. 6 infra.
} 
material for the Informatics program coordinator and faculty to consider. ${ }^{4}$ But the results raised other questions, including, "What help may the student success literature give to address ' $W$ ' behaviors - whether taking a ' $W$ ' (dropping a class) or taking a ' $W$ ' (dropping out of college)?” 5 Also, "What insights do studies of withdrawal offer? In seeking answers to these and related issues, the authors have since reviewed the literature of withdrawal, revisited ' $W$ '-relevant topics within studies of retention and persistence, and looked more deeply into the potential implications of their case study, each resource shaping the present article. They encourage readers to consider the ideas and practices reported here, as well as the opportunities they suggest to assist students to make wise decisions about withdrawals.

\section{The 'W': Reward, Risk, and Other Insights}

The choice to drop a course or to leave college lies with the student, who may lack the necessary counsel to assess the situation fully. While some students may check with an advisor or instructor, many may just disappear. Even if they have viewed their schedule planner for options, how likely are they to gather the right kind of information and to weigh their choicesat a time often given to an urgency for closure in the moment? Yet for educators to assist them effectively, they must know more about the shaping influences that may underlie such pressure. In terms of withdrawal from college, Tinto (1994) found that $20 \%$ of these acts were involuntary. Of the $80 \%$ remaining, poor grades were not a common factor. Students were more likely to flee for non-academic reasons: lacking commitment, making a poor adjustment, having unclear goals, finding a course irrelevant, or feeling isolated as a mismatch to the institution or as not belonging in college. Could factors behind course withdrawal be similar?

In the authors' case study for the student success task force, they were surprised to find that many of the Informatics course drop-outs had also left college within the five semesters reviewed. They wondered what cognitive and non-cognitive influences may have motivated their decisions. How did they feel about themselves at the time? Did newer students perhaps bring inhibiting preconceptions to college, such as family issues, societal conditions, or negative messages experienced in school (Kramer, 2007)? Although the local design did not include a student follow-up, these questions prompted the authors to study both the literature on withdrawal and on student success. ${ }^{6}$

\footnotetext{
${ }^{4}$ Informatics was chosen due to a co-author's access as program coordinator and course instructor of the study's five sections of INFO-I101 that provided the data.

${ }^{5}$ Textual use of the ' $w$ ' refers to a course withdrawal, when contrasted with a ' $W$ ' as withdrawal from college. Otherwise, ' $\mathrm{W}$ ' refers generically to either kind of withdrawal.

6 The authors' university serves 5750 undergraduates: traditional/non 71\%/29\%; male/female 40\%/60\%; Caucasian/non 85\%/14\%; in-state out 67\%/33\% (representing 16 in-state counties, 14 states, and 36 foreign countries); commuters/non 70\%/30\%; student-faculty ratio 16:1; full/part time faculty 46\%/54\%; with class sizes $<20=29 \%$; $<20-49=69 \%$; $>49=2 \%$.
} 


\section{Withdrawal Behaviors in a Local Case Study}

\section{Methodology}

As part of their inquiry on the ' $\mathrm{W}$ in a STEM field, the authors used final grade rosters from five sections of Introduction to Informatics, INFO-I101, which served as a gateway for program admission to the Informatics major on their campus. Pre-majors had to attain a grade of $\mathrm{C}$ or higher. They took the course between fall 2010 and spring 2014, each section averaging 20 students. Transcript review of the sample indicated whether each participant had re-taken the course, withdrawn from one or more other courses, and had either graduated, remained actively enrolled, or left the university. The Student Information System provided demographic information on age, gender, full or part-time status, and class year.

\section{Findings}

Drill-down analysis of these data yielded the results reported in Table 1:

\section{Table 1}

W Data for INFO-I101, Fall 2010-Spring 2014

\begin{tabular}{lc}
\hline Sample Size (total unique 'W' grades) & 16 \\
\hline Average age of students who took a 'W' & 27 yrs. \\
\hline Gender composition of those students (M/F) & $63 \%$ / 37\% \\
\hline Combined Percentage of Juniors and Seniors & $19 \%$ \\
\hline Combined Percentage of Freshmen and Sophomores & $81 \%$ \\
\hline Percentage of students with a prior 'W' history & $63 \%$ \\
\hline Percentage of students who later retook the course after once withdrawing from it & $12 \%$ \\
\hline $\begin{array}{l}\text { Percentage of students who did not retake the course after once withdrawing } \\
\text { from it }\end{array}$ & $88 \%$ \\
\hline
\end{tabular}

\section{Discussion}

Data analyses raised several questions for the authors. For instance, what precursors of course withdrawal could have been discernible to the instructor? What responsibilities may faculty have to intervene in such cases? How did campus ' $W$ ' policy help or hinder a chance to do so, prior to withdrawal? Of the 16 students who withdrew from INFO-I101, 88\% had not re-taken the course, thus never gaining admission to the major. Over $90 \%$ of them had been attending college full time. Yet a records check for persistence revealed that all had left the university, whereas all students who had re-taken the course had become majors and progressed to being seniors by fall 2014.

Regarding other attributes of the withdrawn students, $43 \%$ had no prior history with taking a ' $W$ ' and over half had a GPA of 2.0 or higher, which suggests that non-academic factors may have had some effect. But given the average age of 27, maturity appears not to have been an influence in opting for the ' $\mathrm{W}$.' On the other hand, perhaps taking a course in a college field not 
previously studied in high school led some students to lack confidence or to find the subject matter unappealing. Performance anxiety may have been involved - whether directly or in association with the baggage of anxious-making prior experiences. On the other hand, gender results raised no flag, as the 2:1 ratio of male to female students is not unusual in STEM fields. However, two demographics warrant further inquiry: the 2:1 ratio of withdrawals by students with a 'W' history and the 4:1 ratio of freshmen and sophomores to juniors and seniors.

\section{Implications}

Hindsight has suggested additional ways for the authors to have informed their case study: 1) comparing the demographic categories through cross-tabulated ratios between the sample of withdrawn students and the general population of all students in the five course sections and 2) using an interview/focus group process to probe student decisions. "What were their considerations for retaking the course or not?” What lapse of time was involved in deciding to withdraw and/or to sign up again for the course, if at all?" The case also indicated prospects for future study of ' $W$ ' behaviors: 1 ) a more robust design (e.g. to look for significant correlations), 2) a comparison of gateway courses to several key majors for ' $W$ ' and/or ' $W$ ' patterns, and 3) examining ' $w$ ' and/or ' $W$ ' behaviors in pre-requisites to gateway courses or in others that block timely progress to enrollment in college-level math or writing. Moreover, important work could be involved using the insights and shortcomings of the literature on withdrawal.

\section{Withdrawal Literature: Insights and Shortcomings}

The reward of dropping a course is well known to students, as university policy on the ' $\mathrm{W}$ ' allows some flexibility to accommodate extenuating circumstances while in college. Nelson (2009) has applied the term "wisdom" to this type of withdrawal decision, finding ample historical evidence in which students maintained their plans to graduate, notwithstanding course withdrawal. Since the "progressive" era of the earlier $20^{\text {th }}$ century, pre-college institutions have generally acknowledged that learning should take account of the student's psychological needs as a factor of instruction (Clasen and Bowman, 1974). But in higher education, it was only in the later part of the century that institutions moved away from a "subject-centered" focus-in which taking a 'w' was perceived as "wasteful”- - to a "student-centered" approach that now recognizes some course withdrawals as potentially wise (Fahy,1973; Rump \& Greet, 1975).

Contemporary perceptions of course withdrawal may still be similarly unfavorable, as marks on a transcript, a 'W,' 'WU,' or 'WD' remain visible. If recurring, these symbols may give pause to committees for hiring, program admission, or scholarships. Though interviewees may offer valid reasons for them, the chance of progressing to that point may be slim. ${ }^{7}$ Nor does the withdrawal literature alleviate this concern. Wheland, Butler, Qammar, Katz, and Harris (2012) have found university systems who conducted a mandatory review of grade distributions in which excessive W's were considered a fault of faculty; in other cases, universities have held the student responsible and restricted withdrawal credit hours. Still other institutions have taken a no-tolerance stance: students who cross the permissible ' $W$ ' threshold are subject to automatic program dismissal (GSCIS, 2014; SoBI, 2008; CoN, 2008; and HSSP, 2015). It would also be useful

\footnotetext{
${ }^{7}$ Instructors sometimes suggest course withdrawal to low-performing students (Osborn, 2001). Yet their alertness to how taking a w' may affect students' immediate and long-term future, would position faculty to render more fully informed assistance.
}

Journal of the Scholarship of Teaching and Learning, Vol. 16, No. 6, December 2016. 
to know that, to some students, ' $\mathrm{W}$ ' policies may seem like a form of punishment, which may impact their self-esteem, lead them to struggle with coping tactics, or in more extreme cases, induce them to resort to a self-defeating behavior, like perfectionism.

To explain further, Pritchard, Wilson, and Yamnitz (2007) have found a relationship between negative psychological repercussions and taking a ' $w$ ' that may also delay students' academic progress. One correlation points to gender as a function. For example, males are more likely to reject or ignore negative feedback than to consider it a statement about themselves. Although females' self-concepts associate favorably with positive performance feedback, the opposite effect tends to occur when females encounter the negative (Mickelson, 1989; Correll, 2001; Wigfield and Eccles, 2002). As a case in point, Crosnoe, Riegle-Crumb, and Muller (2007) have discovered that females' taking a ' $W$ ' associated it sufficiently with self-doubt to have reported a reduced self-concept.

Notwithstanding research on the potentially negative psychology of course withdrawal, studies in the ' $W$ ' literature have primarily addressed poor performance, generally indicated by the number of ' $\mathrm{D}, \mathrm{F}, \mathrm{W}$ ' results for a given course. Typically, institutions have focused on those with the highest rates. According to Guskey (1994), this approach commonly identifies the relevant courses, compares their non-passing rates to a pre-set value, discerns patterns, andwhere rates have increased-and reviews attempted strategies to enhance performance and their outcomes, to suggest future directions for inquiry. Another limitation of the ' $W$ ' literature is that its studies tend to be older, dating back as much as 40 years: Deren, 1969; Fahy, 1973;

Lunneborg, Lunneborg, \& Wolf, 1974; and Rump \& Greet, $1975 .{ }^{8}$

More recent ' $W$ ' studies are problematic in other ways. In one instance, Hall, Smith, Brockman, Ramachandran, and Jasin (2003) surveyed students immediately after they left their courses. But aiming to inform the institution on policy, the researchers gave the results to administrators, with a recommendation to offer tutoring. In the case of single-focused studies, such as looking at student personality traits or at socioeconomic issues, the results failed to produce significant outcomes (Lounsbury, Saudargas, \& Gibson, 2004; Clague, 2014). Further, Richie \& Hargrove (2005) and Stucky (2008) have yielded contrary outcomes. Finally, Michalski (2011) has characterized recent studies of the ' $W$ ' as largely unhelpful, due to the changing demographics of today’s college student populations.

Consequently, to the most-asked question- “Why do students withdraw?"-many answers seem viable and several appear to be multi-faceted. In this context, the writers turn to the literature on student success.

\section{Student-Success and Student-Centeredness}

\section{Progressive Means, Practical Ends}

Major changes in primary and secondary education in the last century emphasized the needs of the learner, shaped by progressives like John Dewey, Maria Montessori, and Carl Rogers (Richards, 2014). But since the 80s and 90s, growing societal and economic pressures to retain and graduate college students have pushed pragmatism to the fore in higher education. "Bolstered by federal incentives to encourage innovation in the classroom," student-centeredness and whole-learning interventions have become prevalent in recent studies, according to the

\footnotetext{
${ }^{8}$ For an exception, see Andres \& Carpenter (1997).

Journal of the Scholarship of Teaching and Learning, Vol. 16, No. 6, December 2016. josotl.indiana.edu
} 
Stanford Center for Opportunity Policy in Education (in Richards, 2014). As a result, many tested strategies now exist whose application may assist faculty, advisors, and administrators to re-dress poor academic performance and psychological setbacks, both in their own right and in order to help students to make informed course withdrawal decisions.

This work becomes the more urgent in the contemporary context in which public colleges and universities rely increasingly on tuition to supplement shrinking revenues in the face of legislative cutbacks to higher education, as well as shifts in funding formulas, based on degrees awarded rather than enrollment. Institutions are avidly pursuing more impactful ways to retain students and to accelerate time to a degree through innovations such as centers for writing, math, science, mentoring, tutoring, testing and student development. Non-academic measures have included counseling centers, as well as centers for adults and veterans and even for child-care. Some institutions are collaborating with others to enhance student-achievement programming. As a case in point, the American Association of Colleges and Universities has recently launched a project for "Re-Imagining the First-Year Experience," bringing together faculty and administrators of 44 institutions around the country. Following a master syllabus and working both individually and cooperatively, member teams are pursuing goals, objectives, and outcomes over a three-year period to enhance the freshman year. ${ }^{9}$

To make best use of institutional resources to improve retention and graduation rates, colleges and universities are relying on data-informed assessment of initiatives to learn which of them may make the most difference. For example, evaluative measures have compared campuswide rates of retention and graduation, transfer success, time to degree, improvement of grade point averages, and reduction of gateway courses with high ' $\mathrm{D} / \mathrm{F} / \mathrm{W}$ ' rates (Kramer, 2007). In this context, the writers next consider the integrative manner in which literature on student success considers both the academic and the affective, both student achievement and satisfaction, and both short-term and long-term strategies_-without presuming to know what students think or feel (Levitz, Noel, \& Richter, 1999, p. 37).

\section{Whole-Student Strategies}

Kuh, Kinzie, Schuh, and White (2005) have investigated the attributes of public and private institutions known for higher-than-predicted graduation rates and levels of student satisfaction. Their results address cognitive and non-cognitive factors shown to be effective to promote student success in different ways. From a classroom perspective, outcomes have pointed to high performance, sufficient time on task, and support of students through their academic challenges. Over 18 months and using on-site visits and cross-site analyses of 20 colleges and universities, these researchers have found that these commonly identified educational components also fared well on measures associated with the National Survey of Student Engagement (NSSE, 2015): level of academic challenge, active and collaborative learning, student-faculty interactions, enriching educational experiences, and offering a supportive campus environment.

Other studies cohere with these findings in recommending pedagogies that consider students' potential academic and affective concerns, being more apt to evoke a will to work through challenges (Rothman, 2011). For instance, to foster understanding of course content and patience for an intensive learning environment, Pascarella and Terenzini (2005) have pointed to

\footnotetext{
${ }^{9}$ The authors are part of the campus team effort under AAC\&U leadership working on multiple projects, such as removing policy barriers, examining gateway courses, investigating new technology, cultivating "growth mindsets," and others.
}

Journal of the Scholarship of Teaching and Learning, Vol. 16, No. 6, December 2016. 
group problem-solving and peer teaching among the beneficial ways to engage students' classroom participation and time on task. Other methods for deeper learning have involved ongoing practice of course-essential skills, facilitating students to connect new knowledge with prior learning, giving them timely feedback, and framing their academic challenges as resolvable issues whose solutions are personally meaningful.

High Impact Practices (HIPS) also offer faculty a set of content and methods for student learning which combine curricular and co-curricular motivations to improve student performance and persistence. They include collaborative learning, diversity (global learning), learning communities, first-year experiences, undergraduate research, applied learning (e.g. service learning and internship opportunities), common intellectual experiences, capstone courses and projects, as well as writing intensive courses (Kuh, 2013; Kuh \& O’Donnell, 2013; Kuh, Kinzie, Schuh, and Whitt, 2010). HIPS associate also with socio-psychological influences coherent with students' self-reports of high satisfaction in a number of surveys. ${ }^{10}$

Kuh (2013) has found correlations between HIPs practices and survey outcomes such as NSSE, in which students have self-reported gains in GPA and progress toward a degree. Kuh has credited them with engaging learners' pursuit of deeper meaning. To illustrate, they seem to have generated a sense of fulfillment in connecting students to the subject, the instructor, and their peers, in constructing knowledge together. Participation in collective knowing of this kind has correlated with a $25 \%$ rate of improved retention (Tinto, 2012). Student success literature has also found that collaborative learning appeals to the whole-person (Kramer, 2007).

Farrington (2013) has similarly applauded generating student instructional experiences that appeal to the intellect and the affect. "Mental contrasting" is an example that seems both to enhance achievement and to move students' will to keep after a challenging goal. Based on their study of meta-analyses, Gollwitzer, Oettingen, Kirby, Duckworth, and Mayer (2011) have characterized this process as planning for success: 1) students first envision their goals and imagine themselves achieving them; 2 ) then they anticipate potential barriers and devise in advance strategies to overcome them-while keeping the desired outcome in view.

Mindset growth represents another line of thought on whole-person instruction. In The New Psychology of Student Success, Carol Dweck (2007) posits that whether students may be willing to face a challenge depends in part on their having a positive or "growth" mindset in which they accept trial and error and work hard to succeed. In contrast, students with a "fixed" mindset may be reluctant to take risks, believing intelligence for particular knowledge or skill to be innately limited. Tough (2012) speaks of this fear of failing even among students who have achieved success in other areas. Dweck cautions that to promote a growth mindset is not about preaching, cheerleading, or raising false expectations. Rather, it requires showing students how to learn through challenge by doing honest critique. Facilitating this mindset includes student buy-in to revise and to stay for the long haul. Blackwell, Trzeniewski, \& Dweck (2007) and Fensterwald (2015) have observed students patiently improving even as early as primary school.

National and regional non-profit foundations also support the prospect of growth through learning. For example, since 2010, the William and Flora Hewlett Foundation has funded projects for deeper learning especially featuring "children and youth in higher poverty communities" (Farrington, 2013, p. 2). In connection with research for the University of Chicago's Consortium, Farrington's inquiry has acknowledged academic mindset as a vital

\footnotetext{
${ }^{10}$ See the NSSE Institute Project DEEP Related Papers at http://nsse.iub.edu/institute/; also see the Ruffalo NoelLevitz College Student Inventory (2015), and the Gallup-Purdue Index (Ray \& Kafka, 2014).
}

Journal of the Scholarship of Teaching and Learning, Vol. 16, No. 6, December 2016. josotl.indiana.edu 
whole-person element of motivating students' "underlying self-perceptions of their own ability to succeed" (p. 7). ${ }^{11}$

Oyserman (2009) characterizes motivation as choosing to act one way over another in relation to a sense of being in the world. She believes that human identities - even of childrenare constructed in the dynamics of cumulative experience that move an individual to continue the same behaviors absent reasons to do otherwise. Her recent book Pathways to Success through Identity-based Motivation (2015) theorizes and evidences these ideas. She recommends the kinds of interventions that evoke students' trust in the prospect of their future achievement. For example, Pathways ties early education to a young person's natural drive to succeed. But problems in school and in life may dull and distance what once seemed feasible. Recounting examples drawn from meta-analyses, Oyserman lays fertile ground for scholarly teachers and teacher scholars to excavate, perhaps including action research in classroom to implement and test student success strategies. ${ }^{12}$

Similarly, college students who develop confidence by seeing themselves doing better are more likely to be self-sustaining through a challenge, especially with timely support. In the past decade, the concept of grit has been correlated with an ability to persist or persevere to sustain a goal. Duckworth's grit studies operationally define the term as "perseverance and passion for long-term goals," combining an interest in something with a passion to get it done, such as to pursue a challenging course and to finish a college degree (Duckworth, Peterson, Matthews, and Kelly, 2007, p. 1087). After developing a scale to measure grit, ${ }^{13}$ Duckworth and colleagues gained access to 1200 West Point freshmen ready for the institution's rigorous course of summer training (Duckworth \& Quinn, 2009). Results established grit as a better predictor of drop-outs than the Academy's own "complex" test of the "whole cadet” (in Tough, 2012, p. 75). Duckworth considers it a way to explain "why some persons "accomplish more than others of equal intelligence" - in a way that goes beyond IQ and "conscientiousness" (Duckworth, Peterson, Matthews, \& Kelley, 2007, p. 1087).

The many student-centered approaches considered thus far suggest that, under the right set of circumstances, college can provide a protected space in which to stretch the learner's comfort zone in order to push beyond the familiar (Hoerr, 2013). Whether a quality like grit can be actually "taught” (Schectman, DeBarger, Dorsife, Rosier, \& Yarnall, 2013), or is merely “caught” by example_-in telling and hearing one’s own and others' stories of perseverancegrowth in resilience arguably merits a place in one's toolkit for success in learning and living.

Two decades ago Land and Hannafin (1996) called on participants at the National Convention of the Association for Educational Communications and Technology to create learning environments "rooted in psychological, pedagogical, technological, cultural, and pragmatic foundations" driven by new knowledge of how students "think and learn” (p. 396). On the other hand, Nelson (2009) cautioned that little is known about how students cope with the struggles that lead them to decide one way or another. Nonetheless, thanks to studies forming the literature of student success, educators may access a number of methods shown to enhance learning, retention, and persistence in college.

\footnotetext{
${ }^{11}$ Also see Blackwell, Trzensniewski, and Dweck (2007)

12 “Action research" refers to a qualitative form of study in which the actor (e.g. an instructor) investigates how to improve something (e.g. an instructional method) for the benefit of self or others (e.g. instructing students). For a case in point, see Wyandotte, A. (2009).

${ }^{13}$ The grit measure has since been refined to an 8-point scale called the “Grit-S.” See Duckworth and Quinn (2009).
}

Journal of the Scholarship of Teaching and Learning, Vol. 16, No. 6, December 2016. 
Classroom faculty spend the most time with college students and are the persons on campus whom they most respect. Arguably, they should be first responders to observed or selfreported difficulties. ${ }^{14}$ Moreover, their timely instructional counsel could help to promote students' making informed decisions that also factor in consequences that they otherwise not consider. However, this view presumes that faculty are in the know about what students may contemplate. Yet concerning the prospect of course withdrawal, at the authors' university it is strictly an online process, lacking a built-in intervention. Students' disappearance may be instructors' first notice of course withdrawal, as was the case in the Informatics study.

In that light, as part of the university's participation in the AAC\&U's "Reimagining” project, a policy audit has been conducted, with a new course withdrawal policy about to be heard by the Academic Policy Committee. By its provisions, when students go to the withdrawal website to give notice of their intent to withdraw, a 72-hour hold is triggered, with notices to the instructor, advisor, and Office of Financial Aid. They determine how and what to communicate to these students before the hold expires. At the very least, they will be given timely information to consider. When the hold is lifted, they may submit or retract their intent to withdraw. This approach recognizes that course withdrawals are sometimes warranted, or perhaps even unavoidable.

\section{Suggested Interventions Surrounding Withdrawal}

Knowing that students will continue to withdraw from their courses and from college, an institution would benefit from strategies to bring students back again. Below, the authors suggest some common sense interventions.

\section{Providing a positive withdrawal experience}

- A positive course withdrawal experience ${ }^{15}$ for both student and institution could be part of the groundwork for retaking classes or returning to college. One can seldom underestimate the power of a word-of-mouth or of planting ideas for future action.

- Institutions could consider withdrawal as an act of the whole person-working from the outset to bring them back. But more often, students fill in forms, answer survey questions, scout for approval signatures, and perhaps attend a pro forma interview.

- To expedite timing, the university Bursar could perhaps offer the student a discounted rate toward tuition to re-take the class the next semester.

\footnotetext{
${ }^{14}$ Results of student self-reports in the Purdue Gallup Index (Ray \& Kafka, 2014) revealed factors impacting students in one of three ways: leading them to thrive, to struggle, or to suffer. Meaningful engagement with faculty was high on the list for thriving, with twice the benefit when faculty also offered caring support for them as individuals, encouraged their pursuit of goals and dreams, and excited them to learn. www.insideindianabusiness.com/_newsitem.asp?id=65008
} 
Dear student_name ,

We noticed that you withdrew from [Course " $X$ "] this term. To help you recover from this setback, we are offering you a $25 \%$ tuition discount to retake it next semester.

When paying your next bill, present this official notice to the Bursar to receive this courtesy.

Sincerely, University Bursar

XYZ University

\section{Re-Engaging the withdrawn student}

- An academic advisor could automatically send students a revised plan for the next semester that includes re-taking one or more courses.

- An instructor could send a short personal note to invite students back next term and perhaps encourage an office visit to discuss how to better prepare them. For example, a simple note may say,

Dear student_name,

I have learned of your recent withdrawal from class. You will be missed, but I hope to see you back again next semester.

Retaking the class soon will benefit you because you already have some insight on which to build from your recent experience. I am saving your assignments in the hope that you will set up an appointment with me before the next term to discuss what might help you to better prepare for that experience.

Sincerely Professor XYZ [Course X]/Contact information 
- A unit coordinator or dean in the students' major or pre-major could send a personal note before the next registration period to layout and encourage steps to resume progress (e.g. retaking the course or returning to campus), perhaps offering a priority registration to ensure the chance for a seat in classes likely to fill quickly.

Dear student_name ,

We noticed that you have withdrawn from Course $\mathrm{X}$ this semester. It is offered next semester, and we are hopeful that you will retake it and get back on track with your graduation progress with us.

Course X can fill during semester pre-registration. So to help you stay on track with your graduation plan, we are willing to extend to you a priority registration into Course $\mathrm{X}$ if you are interested. To request it, just bring this letter and your University ID card to the departmental advising office before $4 \mathrm{pm}$ on $\mathrm{xx} / \mathrm{xx} / \mathrm{xxxx}$.

Sincerely [contact information]

Employing communal strategies to bring students back

- Models from alumni recruitment could assist institutions to collect updated student information, find ways to develop ongoing campus commitment, be persistent in contacting those who leave, and join a social with an academic reason to come back to campus. ${ }^{16}$

- Likewise, methods in business may help institutions to retain or to re-engage absent students-an approach used frequently by casinos.

- Additional motivation may derive from institutions who employ so-called "social proof" techniques, such as testimonies for withdrawn students that many like themselves have successfully returned to college when the time is right.

- Also, gamification techniques like those reported in Huang and Soman (2013) may offer plausible tactics for motivating desired behaviors like returning to college.

\section{Conclusion}

This research has explored the limitations of the literature on the ' $\mathrm{W}$ ' in juxtaposition to the promises that contemporary research has associated with student success. It has also presented the authors' limited case study in which students who withdrew from and failed to retake the

\footnotetext{
${ }^{16}$ Interested readers will find detailed research in Shannon \& Bylsma (2006).

Journal of the Scholarship of Teaching and Learning, Vol. 16, No. 6, December 2016. 
introductory course to Informatics were also found to have withdrawn from college. More particularly, the essay has presented a foundation for educators to experiment with student success strategies in their own classrooms as scholarly teachers, or in their own scholarship of teaching. Indeed, these are the acts of concerned educators, representing the kind of work that caring teachers and scholars already do. They raise questions and pursue answers. They read, apply, and test the literature in their fields. They raise consciousness of the wasteful acts and promote the wise. They also advocate for positive change so that learning and learners may thrive. In short, they understand that "the success of an institution and its students are inseparable” (Levitz, Noel, \& Richter, 1999, p. 31).

\section{References}

Andres, L., \& Carpenter, S. (1997). Today's higher education students: Issues of admission, retention, transfer, and attrition in relation to changing student demographics. British Columbia Council on Admissions and Transfer. Vancouver: Education Resources Information Center.

Blackwell, L. S., Trzeniewski, K.H., \& Dweck, C.S. (2007). Implicit theories of intelligence predict achievement across an adolescent transition: A longitudinal study and intervention. Child Development, 78(1), 246-263.

Clague, P. (2014). Why trade students withdraw from their courses: Students' perspectives. New Zealand: Unitec Institute of Technology.

Clasen, R. E., \& Bowman, W. E. (September 1974). Toward a student-centered learning focus inventory for junior high and middle school teachers. Journal of Educational Research, 68(1), 9-11.

CoN. (2008). Undergraduate nursing student handbook. Purdue University-Calumet. Retrieved from http://academics.pnw.edu/nursing/undergraduate-handbook-toc/

Correll, S. J. (2001). Gender and the career choice process: The role of biased self-assessments. American Journal of Sociology, 106, 1691-1730.

Crosnoe, R., Riegle-Crumb, C., \& Muller, C. (2007). Gender, self-perception, and academic problems in high school. Social Problems, 54(1), 118-138.

Deren, S. (1969). Students who withdraw from courses: A descriptive analysis. Hofstra University, Center for the Study of Higher Education. Hempstead, N.Y.: Education Resources Information Center.

Duckworth, A. L., Kirby, A., Gollwitzer, P. M., \& Oettingen, G. (2013). From fantasy to action: Mental contrasting with implementation intentions (MCII) improves academic performance in children. Social Psychological and Personality Science, 4, 745-753.

Duckworth, A. L., \& Quinn, P. D. (2009). Development and validation of the Short Grit Scale (GRIT-S). Journal of Personality Assessment, 91(2), 166-174. 
Dweck, C. S. (2006). Mindset: The new psychology of success. New York: Ballantine.

Fahy, P. (1973). Psychological aspects of student wastage. Studies: An Irish Quarterly Review, 62 (247/248), 195-204.

Farrington, C.A. (2013). Academic mindsets as a critical component of deeper learning. Retrieved from http://www.howyouthlearn.org/pdf/White_Paper_Academic_Mindsets_as_a_Critical_Compone nt_of_Deeper_Learning_Camille_Farrington_April_20_2013.pdf.

Fensterwald, J. (2015, November 23). There's more to a growth mindset than assuming you have it. Retrieved from http://edsource.org/2015/theres-more-to-a-growth-mindset-thanassuming- you-have-it

Gollwitzer, A., Oettingen, G., Kirby, T. A., Duckworth, A. L., \& Mayer, D. (2011). Mental contrasting facilitates academic performance in school children. Motivation and Emotion, 35, 403-412.

GSCIS. (2014). Graduate Catalog. Nova Southeastern University. Retrieved from http://www.scis.nova.edu/documents/catalog.pdf

Guskey, T. R. (1994). Making the grade: What benefits students? Educational Leadership, 52(2), 14-20.

Hall, M., Smith, K., Boeckman, D., Ramachandran, V., \& Jasin, J. (2003). Why do students withdraw from courses? Southern Association for Institutional Research, 01-11. San Antonio, TX.

Hoerr, T. R. (2013). Fostering grit: How do I prepare my students for the real world? Retrieved from ASCD publications at www.ascd.org

HSSP. (2015). Policies and procedures. Drexel University. Retrieved from http://drexel.edu/pennoni/visitingScholars/Policies_Procedures/

Huang, W. H. Y., \& Soman, D. (2013). Gamification of education. Research Report Series: Behavioural Economics in Action. Retrieved from http://inside.rotman.utoronto.ca/behaviouraleconomicsinaction/files/2013/09/GuideGamificatio nEducationDec2013.pdf

Kinzie, J., \& Kuh, G. D. (2007). Creating a student-centered culture. In G. L. Kramer (Ed.), Fostering student success in the campus community. San Francisco, CA: Jossey-Bass.

Kramer, G. L. (Ed.). (2007). Fostering student success in the campus community. San Francisco, CA: Jossey-Bass.

Kuh, G. D. (2013). Assessing underserved students' engagement in high impact practices. In Finley \& McNair, (Eds.) Retrieved from http://www.aacu.org/assessinghips

Kuh, G. D., \& O’Donnell, K., \& Reed, S. (2013). Ensuring quality and taking high-impact practices to scale. (Washington, DC: Association of American Colleges and Universities.) 
Kuh, G.D., Kinzie, J., Schuh, J.H., \& Whitt, E. J. (2010). Student success in college: Creating conditions that matter. San Francisco, CA: Jossey-Bass.

Land, S. M., \& Hannafin, M. J. (1996). Student-centered learning and interactive multimedia: status, issues, and implications. Contemporary Education, 68(2), 94-97.

Levitz, R. S., Noel, L., \& Richter, B. J. (1999). Strategic moves for retention success. In G. H. Gaither (Ed.). Promising practices in recruitment, remediation, and retention). New Directions for Higher Education, n. 108. San Francisco, CA: Jossey-Bass 31-48.

Lounsbury, J. W., Saudargas, R. A., \& Gibson, L. W. (2004). An investigation of personality traits in relation to intention to withdraw from college. Journal of College Student Development, 45(5), 517-534.

Lunneborg, C. E., Lunneborg, P. E., \& Wolf, V. D. (1974). Why do University of Washington students withdraw from classes? Seattle: Education Resources Information Center.

Michalski, G. V. (2011). A text mining analysis of college course withdrawals. Association for Institutional Research Annual Forum, 01-66, Toronto.

Mickelson, R. A. (1989). Why does Jane read and write so well? The anomaly of women's achievement. Sociology of Education, 62, 47-63.

National Survey of Student Engagement (2015). NSSE Survey Instruments. Retrieved from http://nsse.indiana.edu/html/survey_instruments.cfm

Nelson, V. (2009). Should my college student consider withdrawing? College Parent Central. Retrieved from http://www.collegeparentcentral.com/2009/10/-should -my-college-studentconsider-withdrawing-from-a-class/

Noel-Levitz (2015). College Student Inventory. Retrieved from https://www.noellevitz.com/student-retention-solutions/retention-management-systemplus/college-student-inventory

Osborn, E. (2001). When should a student withdraw? The Chronicle of Higher Education. Retrieved from http://chronicle.com/blogs/onhiring/when-should-a-student-withdraw/29424

Oyserman, D. (2015). Pathways to success through identity-based motivation, Cary, N.C.: Oxford University Press.

Oyserman, D. (2009). Identity-based motivation. Journal of Consumer Psychology, 19(3), 250260.

Pascarella, E. T., \& Terenzini, P. T. (2005) How college affects students: A third decade of research, (2), San Francisco, CA: Jossey-Bass.

Pritchard, M. E., Wilson, G. S., \& Yamnitz, B. (2007). What predicts adjustment among college students? A longitudinal panel study. Journal of American College Health, 56, 15-21.

Ray, J. \& Kafka, S. (2014). Life in college matters for life after college. Retrieved from http://www.gallup.com/poll/168848/life-college-matters-life-college.aspx?version=print 
Richie, S. D., \& Hargrove, D. S. (2005). An analysis of the effectiveness of telephone intervention in reducing absences and improving grades of college freshman. Journal of College Student Retention: Research, Theory \& Practice, 6(4), 395-412.

Richards, E. (2014, April 2). Student-centered learning. Retrieved from https://edpolicy.stanford.edu/news/articles/1193

Rump, E. E., \& Greet, N. S. (1975). The characteristics and motivations of students who withdraw without failing. Vestes: Australian Universities' Review, 8(2), 150-160.

Schectman, N., DeBarger, A. H., Dorsife, C., Rosier, S., \& Yarnall L. (2013). Promoting grit, tenacity and perseverance. Critical factors for success in the $21^{\text {st }}$ century. Washington, D.C.: U.S. Department of Education.

Shannon, S. G., \& Bylsma, P. (2006). Helping students finish school: Why students drop out and how to help them graduate. Olympia, WA: Office of Superintendent of Public Instruction.

SoBI. (2008). Academic procedures. The University of Texas. Retrieved from https://sbmi.uth.edu/current-students/student-handbook/academic-procedures.htm

Stucky, T. D. (2008). Investigating whether contacting absent studets increases course success. Journal of the Scholarship of Teaching and Learning, 8(1), 61-71.

Sung, H. K. (2014, February 26). Evidence-based (simple but effective) advice for college students: Microaction and macrochange. Retrieved from https://dus.psu.edu/mentor/2014/02/evidence-based-simple-but-effective-advice-for-collegestudents-microaction-and-macrochange/

Tinto, V. (2012). Completing college: Rethinking institutional action. Chicago: University of Chicago Press.

Tinto, V. (1994). Leaving college: Rethinking the causes and cures of student attrition. Chicago: University of Chicago Press.

Tough, P. (2012). How children succeed: Grit, curiosity, and the hidden power of character. Boston: Mariner Books.

Wheland, E. R., Butler, K. A., Qammar, H., Katz, K. B., \& Harris, R. (2012). What are they thinking? Students' affective reasoning and attitudes about course withdrawal. National Academic Advising Association Journal, 32(2), 17-25.

Wigfield, A., \& Eccles, J. S. (2002). The development of competence beliefs, expectancies for success, and achievement values from childhood through adolescence. In A. Wigfield, \& J. S. Eccles, (Eds.), Development of Achievement Motivation, pp. 173-195. San Diego, CA: Academic Press.

Willging, P. A., \& Johnson, S. D. (2009). Factors that influence students' decision to drop out of online courses. Journal of Asynchronous Learning Networks, 13(3), 115-127. 
Wyandotte, A. (2009). Reciprocal gains in higher order thinking and course content in teaching students to argue and think critically. Journal on Excellence in College Teaching, 20(4), 31-53. 